\title{
Contribution to the study of the Orthoptera diversity through the alimentary diet of some waders in Algeria
}

\author{
Kamel Hamadi ${ }^{1,2,}$, Rachida Gherbi-Salmi ${ }^{3}$, Linda Cheriak-Bouguessa ${ }^{4}$, Sihem Bakour ${ }^{3}$, Riadh Moulaï ${ }^{3}$
}

${ }^{1}$ Laboratoire Dynamique et Biodiversité, Faculté des Sciences Biologique, Université des Sciences et de la Technologie Houari Boumediene, Alger, Algeria

${ }^{2}$ Institut National de Formation Supérieure des Cadres de la Jeunesse Madani SOUAHI, Alger, Algeria

${ }^{3}$ Laboratoire de Zoologie Appliquée et d'Ecophysiologie Animale, Faculté des Sciences de la Nature et de la Vie, Université de Béjaia 06000 Béjaia, Algeria

${ }^{4}$ Université de Tébessa, Faculté des Sciences Exactes et des Sciences de la Nature et de la Vie, 12000 Tébessa, Algeria

${ }^{*}$ Corresponding author: hamadikamel@yahoo.fr

\begin{abstract}
In order to study orthopteric diversity through the alimentary diet of predatory birds, 444 rejection pellets of one heron Bubulcus ibis and the White Stork Ciconia ciconia made it possible to carry out an estimation study of the orthopteric fauna of three regions in Algeria, Rachgoun Island, Bjaia and Tébessa. After analysis of the rejection pellets, a specific richness of 32 species of Orthoptera was recorded for the three studied regions, including 10 Ensifera and 22 Caelifera. The Acrididae family predominates in all the Orthoptera populations collected. The highest centesimal frequencies were noted for Gryllus bimaculatus (37\%) in Béjaia, Pamphagus tunetanus (36.7\%) in Tébessa and Pezotettix giornae (34.73\%) and Calliptamus barbarus $(31.15 \%)$ in Rachgoun Island. This is directly linked to the number of orthopterofauna existing in the field. The diversity of the regions surveyed does not differ much, Rachgoun Island ( $H^{\prime}: 2.22$ bits, E: 0.79), Béjaia (H': 3.14 bits, E: 0.71) and Tébessa (H': 2.13 bits, E: 0.52); with evenly distributed stands with close similarity between Béjaia and Rachgoune Island $(42.86 \%)$ and between Béjaia and Tébessa $(42.10 \%)$. The results thus obtained by this study are similar to those of other sampling methods; presenting the possibility of being combined with other techniques for estimating the abundance of orthopteric fauna in order to obtain results close to reality; precisely in the environments where Orthoptera are subjected to strong predation pressure by the avifauna, knowing that it is quite precise, complementary and does not present any ecological constraints.
\end{abstract}

KEY WORDS Acrididae; Bubulcus ibis; Ciconia ciconia; Pellets.

Received 26.04.2021; accepted 18.08.2021; published online 14.09.2021

\section{INTRODUCTION}

Orthoptera are one of the most used taxonomic groups in ecosystem studies, either in trophic, landscape or environmental management ecology (Jaulin \& Baillet, 2007). Therefore, they are widely distributed and generally abundant insects, which are often distinguished by their fidelity to a specific type of habitat and by their great sensitivity to the evolution of ecosystems. They also form a central taxon in food chains due to their importance in trophic web, especially as food resources for a large number of birds species (Georges et al., 1999; Jaulin, 2009; Badenhausser, 2012).

The White Stork (Ciconia ciconia Linnaeus, 1758) and the Cattle Egret (Bubulcus ibis Linnaeus, 1758 ) are among the bird species whose diet is mainly insectivorous. Orthoptera seems to be the 
most sought prey by these two big waders (Boukhtache, 2008). It has been shown that storks and herons daily consume the equivalent of 10$20 \%$ of their own weight in term of food (Hafner \& Fasola, 1992; Hafner et al., 1993). Studies carried out on the diet of the Cattle Egret have revealed a high consumption of Orthoptera in north Africa (Doumandji et al., 1992, 1993; Bentamer, 1998; Boukhemza et al., 2000; Si Bachir et al., 2001). Likewise, a study of the menu consumed by young White Stork shows that the latter consists mainly of insects (93.5\%) of which Orthoptera represent $52.9 \%$ in biomass (Fellag, 2006).

Several methods of sampling Orthoptera have been described in order to estimate their abundance in different environments (Gardiner et al., 2005; Doxon et al., 2011). The inventory is based on both visual and auditory detection of species (Adam et al., 2015). Listening to and recognizing the chirping of males is a very useful as it makes it possible to identify species which would have gone unnoticed (Boitier, 2005). For this group of insects, the most widely used sampling method is the quadrats or cage sampler method (Gueguen 1989; Tatin et al., 2000). It makes it possible to trap and capture the greatest number of individuals per unit area. The collection of Orthoptera can also be done by using the mowing net method. The surveys of this method makes it possible to know the specific composition of a population of Orthoptera (Voisin, 1986). Among the methods used in studies on Orthoptera, we used the linear index of abundance "LIA" described by Voisin (1986). LIA is to perform different transects $20 \mathrm{~m}$ long, the Orthoptera are identified by the using of a sweep net when needed and determined in situ. In addition to the aforementioned methods, threshing of tree or shrub vegetation above a umbrella could allow to supplement the number of species contacted (Adam et al., 2015). However, with the development of biocoenotic studies, ecological entomologists have sought, by systematizing old methods, or by inventing new ones, to arm themselves with sampling techniques that meet the requirements of quantitative studies (Gillon, 1967; Guéguen, 1989; Tatini et al., 2000). The idea is therefore to launch the first work which contributes to the study of orthopteric diversity thanks to an indirect method of census of orthopterofauna which is based on the analysis of fragments, of consumed species, found in the rejection pellets of the two big waders, the White Stork and the Cattle Egret.
The study of the trophic ecology of these two species was carried out in three geographically distant regions in Algeria. Rachgoune Island in Oran and the Soummam region near Béjaia for the Cattle Egret, and the Tébessa region at the end of eastern Algeria for the White Stork.

\section{MATERIAL AND METHODS}

\section{Study area}

The study was carried out in three regions belonging to different bioclimatic stages. The first site is Rachgoun Island located in Oran, with an area of 16.5 hectares. The island belongs to the semi-arid bioclimatic stage with warm winter and is located in the bay of Beni Saf not far from the town of Ain Temouchent, between $35^{\circ} 19^{\prime} 18.58^{\prime \prime} \mathrm{N}$ latitude and $1^{\circ} 28^{\prime} 49.20^{\prime \prime} \mathrm{W}$ longitude. This bay is $14 \mathrm{~km}$ long, and the island's plateau rises to an altitude of 65 meters with a slight slope of less than $10 \%$. The depth in the water is between 2 and $20 \mathrm{~m}$ (Bouras \& Ramdani, 2013). The second site is the Soummam Valley located near the Béjaia region whose geographic coordinates are $36^{\circ} 38^{\prime}$ to $36^{\circ} 45^{\prime} \mathrm{N} ; 4^{\circ} 51^{\prime}$ to $5^{\circ} 20^{\prime} \mathrm{E}$, belonging to the sub-humid bioclimatic stage with warm winter. This study area is limited to the east and southeast by the Babors to which the Bibans merge further south, to the north by the Mediterranean Sea and to the west by the Djurdjura (D.A.T.B., 1996). The third site is the Tébessa region which covers an area of $13.878 \mathrm{~km}^{2}$. This region is located in the northeast of Algeria $34^{\circ} 15^{\prime}$ to $35^{\circ} 45^{\prime} \mathrm{N}$; $7^{\circ} 30^{\prime}$ to $8^{\circ} 30^{\prime} \mathrm{E}$, belonging to the semi-arid bioclimatic stage with cool winter. It rises to about $960 \mathrm{~m}$ above sea level, and is naturally linked to the immense steppe expanse of the country (Anonyme, 2011) (Fig. 1).

\section{Methodology}

The studied orthopterological fauna results from the analysis of the rejections pellets of adult individuals of the two species of wading birds. Three colonies were collected with a variable number of pellets. 152 and 50 pellets of Cattle Egret are collected respectively at the island Rachgoun in Oran and the Valley of Soummam in Béjaia; and 242 pellets of the White Stork collected in the region of Tébessa.

A total of 444 pellets were analyzed for the three combined regions. The principle of this analysis is 


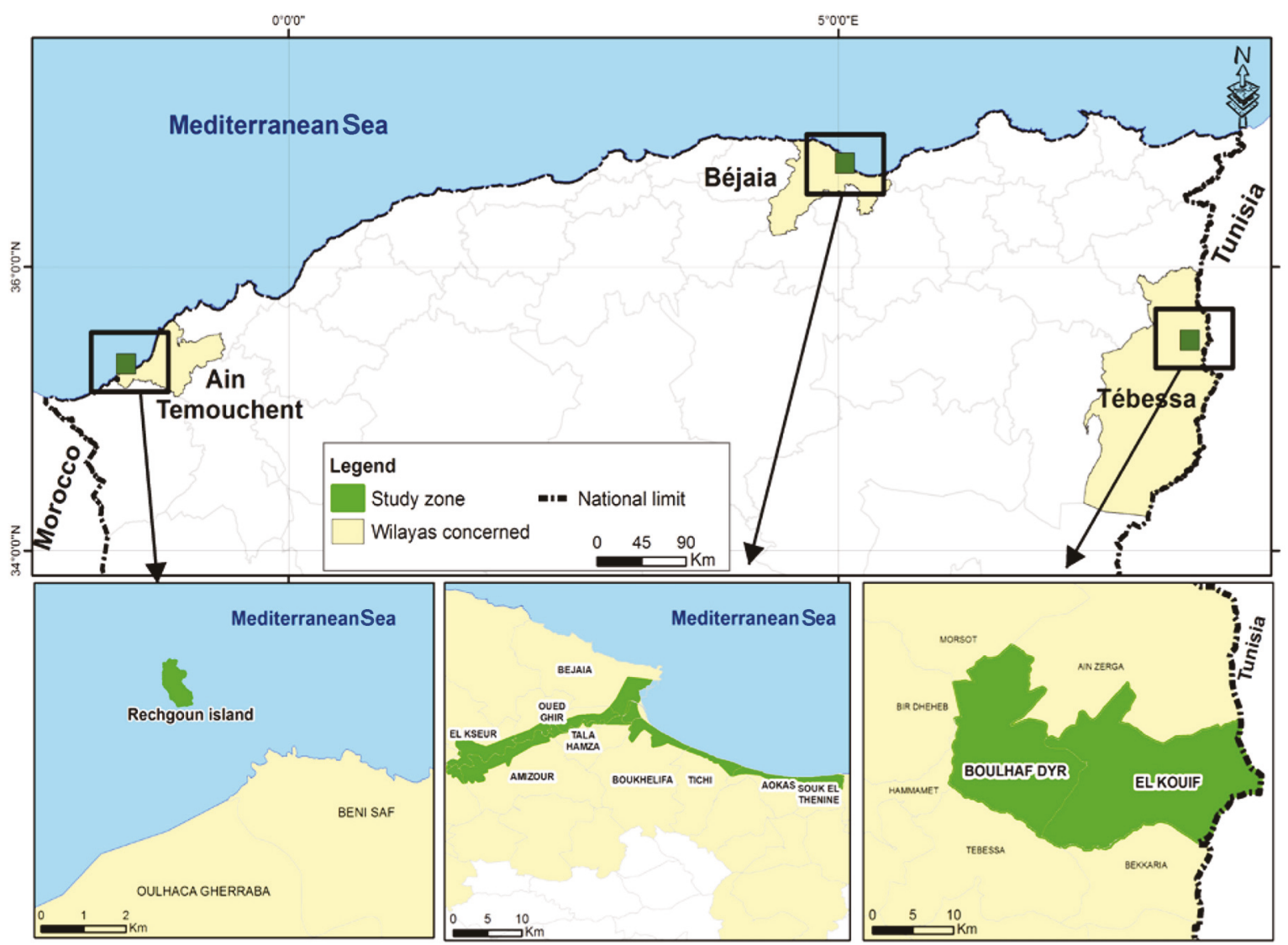

Figure 1. Geographical location of the study regions.

to macerate each pellet in water for five to ten minutes. Once softened, the pellet is peeled and all the sclerotinized parts of the arthropods are recovered and placed in a petri dish. After being observed under binocular magnifying glass, the fragments of Orthoptera are then isolated from the rest of the pieces, using an entomological forceps to be identified using dichotomous keys and boxes from reference collections, namely Chopard (1943), Roques \& Jourde (2013), Louveaux et al. (2020).

For the exploitation of the results we used ecological indices of structure and composition. The first ones are represented by the total richness (S) which corresponds to the total number of species of Orthoptera identified during the analysis of the rejection pellets. The centesimal frequency was calculated for each species recorded. It is the ratio between the numbers of individuals $\left(n_{i}\right)$ of a species over the number of individuals $(\mathrm{N})$ of all combined species (Dajoz, 1985).

For the ecological composition index, the diversity of the orthopterological fauna of the studied sites was estimated using the Shannon-Wiener index $\mathrm{H}^{\prime}$ (Shannon \& Weaver, 1948) where $\mathrm{H}^{\prime}=-\sum \mathrm{q}_{\mathrm{i}}$ $\log _{2} q_{i}$ with $q_{i}=n_{i} / N$ which is the ratio of the individuals $n_{i}$ of the orthopteran-prey species $I$ to the total number of individuals of all combined orthopteran-prey species. The equitability index $\mathrm{E}\left(\mathrm{E}=\mathrm{H}^{\prime}\right.$ / H'max) is calculated for each station, it is the ratio between the diversity H' and the maximum diversity H'max with H'max $=\log _{2} \mathrm{~S}$, where $\mathrm{S}$ is the total specific richness. The value of this index varies between 0 and 1 . It tends to 0 as nearly all staffing correspond to a single species and is close to 1 when each species is represented by the same number of individuals (Ramade, 1984). The calculation of degree of similarity or association of the stations of study was calculated by the Sorensen index $\underline{\mathrm{Cs}}$ (Magurran, 1988), with $\mathrm{Cs}=2 \mathrm{~d} / \mathrm{a}+\mathrm{b} \times 100$, where $\mathrm{a}$ is the number of species present in station $a$ and $b$ the number of species present in station $b$; $d$ is the number of common species in $a$ and $b$.

A principal component analysis (PCA) was carried out for the entire orthopteric population iden- 
tified in the three studied regions in order to best explain the organization of the species in the areas surveyed and to highlight those which are distinctive for each studied region.

\section{RESULTS}

Inventory and classification of orthopteric species identified in the different studied regions

Analysis of the 444 pellets of rejection of the two species of wader, the Cattle Egret and White Stork, has identified a total of 32 species of Orthoptera which is distributed on 6 families and 15 subfamilies. More than half of the identified species richness belongs to the Acrididae family $54.83 \%$, followed by Tettigoniidae 19.35\%, Gryllidae and Pamphagidae with $9.68 \%$ each and Gryllotalpidae and Tetrigidae with $3.23 \%$ each. The specific total richness based on surveyed regions reached respectively 21 species in Béjaia, 18 species in Tébessa and 7 species in Rachgoun Island. The Acrididae dominate with percentages of $61.9 \%$ for Béjaia, $58.82 \%$ for Tébessa and $57.14 \%$ for Rachgoun Island. However, we notice the absence of Gryllidae (Rachgoun Island), Gryllotalpidae (Rachgoun and Béjaia Island) and Tetrigidae (Rachgoun and Tébessa Island) (Table 1).

\section{Frequency of orthopterological species}

The centesimal frequencies of all the combined species of Orthoptera depending on the environmental study. The variations oscillate between $0.11 \%$ for Acinipe algerica and 34.73\% for Pezotettix giornae at Rachgoun Island, $0.13 \%$ for Dociostaurus jagoi jagoi and 37\% for Gryllus bimaculatus in Béjaia, and $0.05 \%$ for each species Anacridium aegyptium, Conocephalus fuscus and Decticus albifrons and $36.7 \%$ for Pamphagus tunetanus in Tébessa. The above species has also been described under Pamphagus marmoratus var. tunetanus Vossler, 1902; it is recognizable by its highly variable coloring, gray-brown marbled with white on the lateral lobes of the pronotum (Louveaux et al., 2020). With a larger size (body length in males 36.5-54.0, in females 45.8-72.0), hind femora ca. 3.8 times longer than high (Benkenana \& Massa, 2017). Some species also present fairly high frequencies and appear to be characteristic of their environment; this is the case of Aiolopus strepens (27.8\%) and Oedipoda fuscocincta $(27.3 \%)$ in Tébessa and of Calliptamus barbarus $(31.15 \%)$ in Rachgoun Island (Table 2).

\section{Shannon-Weaver diversity index and the equitability}

The specific richness of Orthoptera relating to each studied region is 7 species for Rachgoun, 18 species for Tébessa and 21 species for Béjaia. The values obtained from the index specific diversity of Shannon-Weaver show that Béjaia is the most diversified station (4.39 bits) compared to Rachgoun (2.22 bits) and Tébessa (2.13 bits). In terms of equal distribution, the orthopteric species of Rachgoun Island $(E=0.79)$ and Béjaia $(E=0.71)$ appear to be fairly distributed compared to those identified in Tébessa $(E=0.52)$ (Table 3$)$.

\section{Sorensen's coefficient of similarity}

The Sorensen coefficient calculated for the orthopterocoenosis identified for each studied region reveals two very close similarity values between Béjaia/Rachgoun and Béjaia/Tébessa which are respectively $42.86 \%$ and $42.10 \%$. The lowest similarity was recorded between Rachgoun and Tébessa in the order of $25 \%$ (Table 4 ).

\section{Principal components analysis (PCA)}

Axes 1 and 2 of the PCA carried out on the matrix consisting of 3 (studied regions) and 32 (Orthopterological species recorded) is explained by a total inertia ratio of $72.34 \%$, respectively $40.22 \%$ and $32.12 \%$. The abundant species Oedipoda fuscocincta, Aiolopus strepens and Pamphagus tunetanus are represented and stand out from the rest of the point cloud which explains their strong correlation to the two axes and thus contribute positively to their inertia with $27.30 \%, 27.80 \%$ and $36.70 \%$, respectively. Other species are easily readable on the factorial side; this is the case of Calliptamus barbarus and Pezotettix giornae marked by the important effectives in the Rachgoun Island. The region of Béjaia is the opposite of the first two stations and thus marks a negative correlation. The species recorded in this region presented very close numbers (Fig. 2). 


\begin{tabular}{|c|c|c|c|c|c|}
\hline Family & Subfamily & Species & $\begin{array}{l}\text { Rachgoun } \\
\text { Island }\end{array}$ & Béjaia & Tébessa \\
\hline \multicolumn{6}{|c|}{ Underorder Ensifera } \\
\hline Gryllidae & Gryllinae & $\begin{array}{l}\text { Gryllus campestris Linnaeus, } 1758 \\
\text { Gryllus bimaculatus De Geer, } 1773 \\
\text { Sciobia batnensis (Finot, 1893) }\end{array}$ & - & $\begin{array}{l}+ \\
- \\
+\end{array}$ & $\begin{array}{l}+ \\
+ \\
+\end{array}$ \\
\hline Gryllotalpidae & Gryllotalpinae & Gryllotalpa sp. & - & - & + \\
\hline \multirow[b]{3}{*}{ Tettigoniidae } & Conocephalinae & Conocephalus fuscus (Fabricius, 1793) & - & - & + \\
\hline & Phaneropterinae & Odontura algerica Brunner von Wattenwyl, 1878 & - & + & - \\
\hline & Tettigoniinae & $\begin{array}{l}\text { Amphiestris baetica (Rambur, 1839) } \\
\text { Decticus albifrons (Fabricius, 1775) } \\
\text { Platycleis intermedia (Serville, 1838) } \\
\text { Tessellana tessellata (Charpentier, 1825) }\end{array}$ & $\begin{array}{l}- \\
+ \\
- \\
+\end{array}$ & $\begin{array}{l}+ \\
+ \\
- \\
+\end{array}$ & $\begin{array}{l}- \\
+ \\
+ \\
-\end{array}$ \\
\hline \multicolumn{6}{|c|}{ Underorder Caelifera } \\
\hline \multirow{8}{*}{ Acrididae } & Acridinae & $\begin{array}{l}\text { Acrida turrita (Linnaeus, 1758) } \\
\text { Truxalis nasuta (Linnaeus, 1758) }\end{array}$ & - & $\begin{array}{l}+ \\
-\end{array}$ & $\begin{array}{l}- \\
+\end{array}$ \\
\hline & Calliptaminae & Calliptamus barbarus (Costa, 1836) & + & + & + \\
\hline & Cyrtacanthacridinae & Anacridium aegyptium (Linnaeus, 1764) & - & + & + \\
\hline & Eyprepocnemidinae & Eyprepocnemis plorans (Charpentier, 1825) & - & + & - \\
\hline & Gomphocerinae & $\begin{array}{l}\text { Ochrilidia filicornis (Krauss, 1902) } \\
\text { Ochrilidia gracilis (Krauss, 1902) } \\
\text { Dociostaurus jagoi jagoi Soltani, } 1978\end{array}$ & $\begin{array}{l}+ \\
- \\
-\end{array}$ & $\begin{array}{l}+ \\
- \\
+\end{array}$ & $\begin{array}{l}- \\
+ \\
+\end{array}$ \\
\hline & Oedipodinae & $\begin{array}{l}\text { Aiolopus strepens (Latreille, 1804) } \\
\text { Oedaleus decorus (Germar, 1826) } \\
\text { Locusta migratoria cinerascens (Fabricius, 1781) } \\
\text { Oedipoda caerulescens sulphurescens Saussure, } \\
1884 \\
\text { Oedipoda fuscocincta Lucas, } 1849 \\
\text { Oedipoda miniata Lucas, } 1849 \\
\text { Acrotylus patruelis (Herrich-Schaffer, 1838) } \\
\text { Thalpomena algeriana Lucas, } 1849\end{array}$ & $\begin{array}{l}+ \\
- \\
- \\
- \\
- \\
- \\
- \\
-\end{array}$ & $\begin{array}{l}+ \\
+ \\
+ \\
+ \\
- \\
- \\
+ \\
-\end{array}$ & $\begin{array}{l}+ \\
+ \\
- \\
+ \\
+ \\
+ \\
+ \\
+\end{array}$ \\
\hline & Pezotettiginae & Pezotettix giornae (Rossi, 1794) & + & + & - \\
\hline & Tropidopolinae & Tropidopola cylindrica (Marschall, 1836) & - & + & - \\
\hline Pamphagidae & Pamphaginae & $\begin{array}{l}\text { Acinipe algerica (Brunner von Wattenwyl, } 1882 \text { ) } \\
\text { Pamphagus elephas (Linnaeus, 1758) } \\
\text { Pamphagus tunetanus Vosseler, } 1902\end{array}$ & $\begin{array}{l}+ \\
- \\
-\end{array}$ & $\begin{array}{l}- \\
+ \\
-\end{array}$ & $\begin{array}{l} \\
- \\
+\end{array}$ \\
\hline Tetrigidae & Tetriginae & Paratettix meridionalis (Rambur, 1838) & - & + & - \\
\hline 6 & 15 & 32 & 7 & 21 & 18 \\
\hline
\end{tabular}

Table 1. Inventory and classification of orthopterological species identified in the trophic menu of two waders in different regions in Algeria. 


\begin{tabular}{|c|c|c|c|c|c|c|}
\hline \multirow{2}{*}{ Species } & \multicolumn{2}{|c|}{ Rachgoun Island } & \multicolumn{2}{|c|}{ Bejaia } & \multicolumn{2}{|c|}{ Tébessa } \\
\hline & $\mathrm{ni}$ & $\mathrm{FC} \%$ & ni & FC\% & ni & $\mathrm{FC} \%$ \\
\hline Acinipe algerica & 3 & 0.11 & - & - & - & - \\
\hline Acrida turrita & - & - & 5 & 0.32 & - & - \\
\hline Acrotylus patruelis & - & - & 15 & 0.95 & 13 & 0.65 \\
\hline Aiolopus strepens & 407 & 14.44 & 96 & 6.11 & 555 & 27.8 \\
\hline Amphiestris baetica & - & - & 42 & 2.67 & - & - \\
\hline Anacridium aegyptium & - & - & 6 & 0.38 & 1 & 0.05 \\
\hline Calliptamus barbarus & 878 & 31.15 & 276 & 17.6 & 2 & 0.1 \\
\hline Conocephalus fuscus & - & - & - & - & 1 & 0.05 \\
\hline Decticus albifrons & 166 & 5.89 & 23 & 1.46 & 1 & 0.05 \\
\hline Dociostaurus jagoi jagoi & - & - & 2 & 0.13 & - & - \\
\hline Eyprepocnemis plorans & - & - & 70 & 4.45 & - & - \\
\hline Gryllotalpa sp. & - & - & - & - & 2 & 0.1 \\
\hline Gryllus bimaculatus & - & - & 581 & 37 & 15 & 0.75 \\
\hline Gryllus campestris & - & - & - & - & 12 & 0.6 \\
\hline Locusta migratoria cinerascens & - & - & 66 & 4.2 & - & - \\
\hline Ochrilidia filicornis & 280 & 9.93 & 15 & 0.95 & - & - \\
\hline Ochrilidia gracilis & - & - & - & - & 39 & 1.95 \\
\hline Odontura algerica & - & - & 92 & 5.85 & - & - \\
\hline Oedaleus decorus & - & - & 5 & 0.32 & 12 & 0.6 \\
\hline Oedipoda caerulescens sulfurescens & - & - & 37 & 2.35 & 19 & 0.95 \\
\hline Oedipoda fuscocincta & - & - & - & - & 545 & 27.3 \\
\hline Oedipoda miniata & - & - & - & - & 15 & 0.75 \\
\hline Pamphagus elephas & - & - & 16 & 1.02 & - & - \\
\hline Pamphagus tunetanus & - & - & - & - & 733 & 36.7 \\
\hline Paratettix meridionalis & - & - & 2 & 0.13 & - & - \\
\hline Pezotettix giornae & 979 & 34.73 & 120 & 7.63 & - & - \\
\hline Platycleis intermedia & - & - & - & - & 8 & 0.4 \\
\hline Tessellana tessellata & 106 & 3.76 & 16 & 1.02 & - & - \\
\hline Thalpomena algeriana & - & - & - & - & 13 & 0.65 \\
\hline
\end{tabular}




\begin{tabular}{|l|c|c|c|c|c|c|}
\hline Sciobia batnensis & - & - & 58 & 3.69 & - & - \\
\hline Tropidopola cylindrica & - & - & 29 & 1.84 & - & - \\
\hline Truxalis nasuta & - & - & - & - & 14 & 0.7 \\
\hline Total & 2819 & 100 & 1572 & 100 & 2000 & 100 \\
\hline
\end{tabular}

Table 2. Frequency of the 32 species recorded for each studied region.

\begin{tabular}{|l|c|c|c|}
\hline Station & Rachgoun Island & Béjaia & Tébessa \\
\hline $\mathrm{S}$ & 7 & 21 & 18 \\
\hline H'(bits) & 2.22 & 3.14 & 2.13 \\
\hline H'max & 2.81 & 4.39 & 4.09 \\
\hline $\mathrm{E}$ & 0.79 & 0.71 & 0.52 \\
\hline
\end{tabular}

Table 3. The Shannon-Wiener diversity and equitability index calculated for the orthopteric population of each studied region.

\begin{tabular}{|l|l|l|l|}
\cline { 2 - 4 } \multicolumn{1}{c|}{} & & Bejaia & Tébessa \\
\hline Rachgoun & & $42.86 \%$ & $25 \%$ \\
\hline Bejaia & & $100 \%$ & $42.10 \%$ \\
\hline
\end{tabular}

Table 4. The similarity of Orthopterological-prey species according to the studied regions.

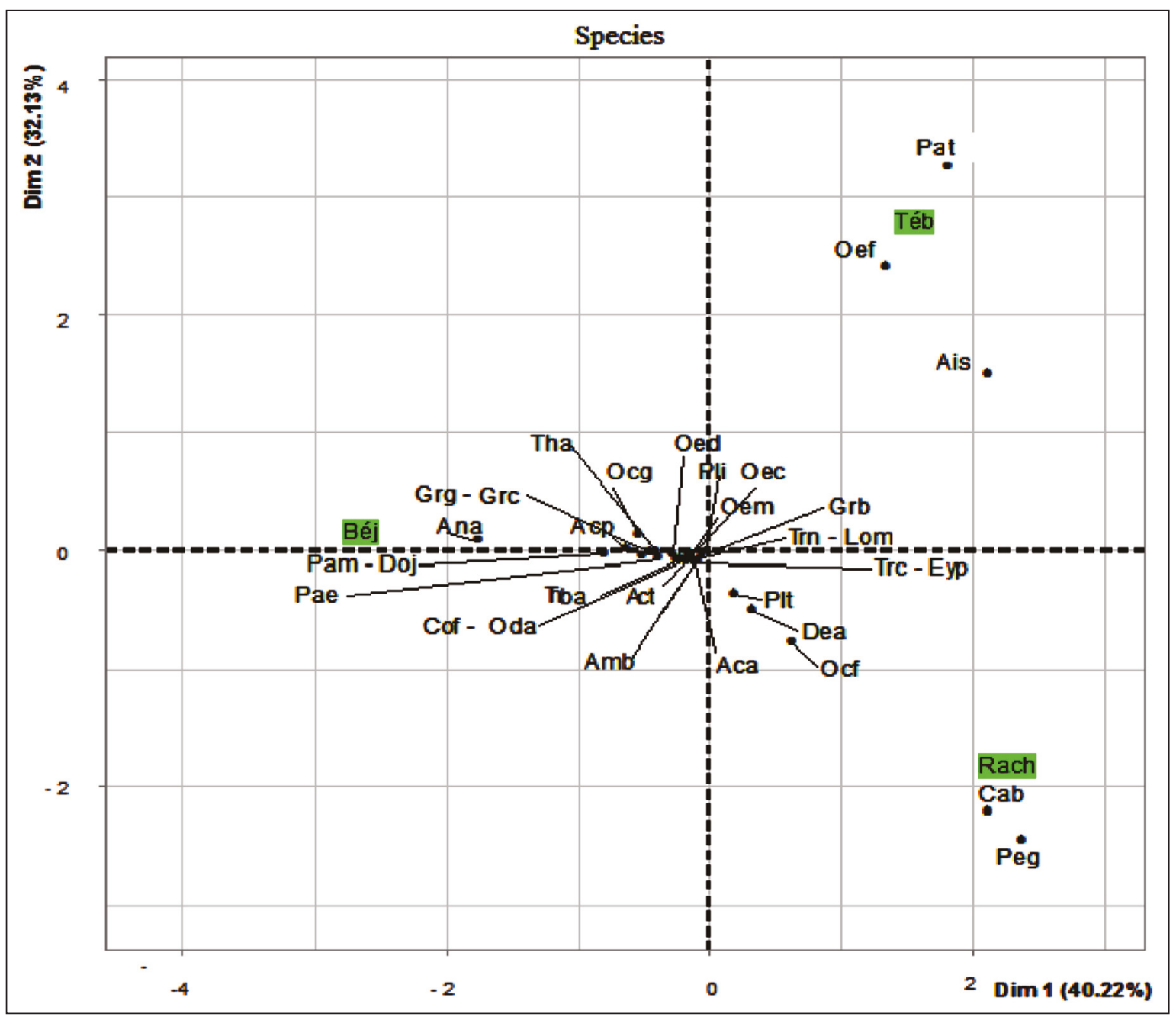

Figure 2. Representation of orthopterological species identified on plan 1-2 of the PCA.

Each label is made up of three letters relating to the specific name. (eg. Cab : Calliptamus barbarus). 


\section{DISCUSSION}

At the level of the studied environments, the collecting of Orthoptera as prey species was made by these two waders which take them directly from their biotope at any time or period of the year, and often in fairly broad weather conditions. The frequencies of the methods often used by researchers to determine the abundance of Orthoptera are in the order of $45.5 \%$ for the sampling with the mowing net, $17 \%$ for the transect method, $13.4 \%$ for the open quadrants, $9.8 \%$ for pit traps and 2 to $5 \%$ for the rest of the counting methods (Gardiner et al., 2005). Samples allow us to know the specific composition of a stand (Voisin, 1986). Indeed, with the study methodology adopted, a total specific richness of 32 species was recorded for the combined three studied regions with 10 Ensifera and 22 Caelifera; respectively, 7 species in the Rachgoun Island, 18 species in Tébessa and 21 species in Béjaia. The sampling of Orthoptera carried out by the method of collecting squares (Gillon, 1967) of 9 $\mathrm{m}^{2}$ revealed a total of 15 and 24 species respectively for the periods 1998 and 2008 in the region of Tébessa (Bouguessa, 2018). Likewise, with the same sampling technique Hamadi et al. (2005) amounted to 14 species in the region of Béjaia. Several studies seem to show a marked preference of the Cattle Egret for insects, in particular Orthoptera (Berdin, 1984). Likewise, Skov (1991) reports that among the invertebrates, the White Stork harvests a great variety of insects and especially Coleoptera and Orthoptera. The study of the diet of two waders in the region of Tébessa has revealed dominance for the class of insects with an occurrence of $30.25 \%$ and $32.1 \%$ calculated for the Orthoptera respectively for the White Stork and Cattle Egret (Sbiki, 2016).

The highest centesimal frequencies calculated for the orthopteric species of the three studied regions were noted for Gryllus bimaculatus (37\%) in Béjaia, Pamphagus tunetanus $(36.7$ \%) in Tébessa and Pezotettix giornae (34.73\%) and Calliptamus barbarus $(31.15 \%)$ in Rachgoun Island. The heterogeneity of the frequencies of each species in relation to the studied regions specifies that the estimation method used is very significant. The two waders did not select the species according to their size or others, but the individuals were taken according to their availability and their accessibility in the environment, knowing that the Orthoptera often appear in aggregate. Pezotettix giornae reveals to be present with a high frequency in Rachgoun Island despite its small size, which is 11 to $15 \mathrm{~mm}$ for males and from 12 to $18 \mathrm{~mm}$ for females (Chopard, 1943). Jaulin (2004) ranks Pezotettix giornae at the top of the list of common species due to its presence in more than a third of these records. Similarly, Puissant (2003) reports that Orthoptera, as a food biomass for the Capercaillie, are not currently a readily available food resource due to the poor size of their populations. This explains the part of each species in the two waders menu that is directly related to the actual existing on land.

The values of the diversity of the orthopteric population of the three studied stations do not differ much, Rachgoun Island (H': 2.22 bits, E: 0.79), Béjaia (H': 3.14 bits, E: 0.71$)$ and Tébessa (H': 2.13 bits, E: 0.52), with fairly distributed stands. However, we note that despite the low value of the total richness recorded in Rachgoun Island $(S=7)$ compared to the two other studied regions, this one presents a homogeneous and well distributed population whose similarity is much closer to the region of Béjaia $(42.86 \%)$, probably due to its proximity to the sea (coastal environment or littoral). Franceschi (1994) reports that the variations observed in the composition of the various Mediterranean island faunas correlate with the size of the geographical area considered. This essential factor does not explain everything; it is necessary to take into account the distance which separates the island from the nearest mainland and the variety of its biotopes. Likewise, another similarity with almost the same percentage was recorded between Bejaia and Tebessa (42.10\%). This allowed, in the region of Béjaia, the designation of two orthopteric populations of common species either with the island environment of Rachgoun or with the plain of Tébessa. The analytical method used has highlighted the Acrididae family as the most representative Orthoptera identified in the three combined studied areas. The same observation has been made by several authors who have worked in these environments with the quadrant enumeration method (Hamadi et al., 2005; Gherbi-Salmi, 2013; Bouguessa, 2018). However, a predominance in numbers was noted for Pamphagus tunetanus (Pamphagidae) in the region of Tébessa thus representing a centesimal frequency of $36.7 \%$ compared to the Orthoptera taken by the two waders.

Ideed, the results obtained during this present study appear to be interesting and are moreover similar to those resulting from studies carried out with 
other sampling methods. The interest of the technique for estimating the abundance of Orthoptera populations by the analysis of rejection pellets lies in its originality and in its possibility of being combined with other methods of studying populations of Orthoptera. Specifically, those suffering from high pressures predation by birds. The known sampling methods reach their maximum efficiency in the open grassy areas, and lose their precision as the vegetation becomes taller and denser (Voisin, 1980). The combined sight and hearing prospecting has greatly increased the efficiency of inventories (Barataud, 2005). It is therefore interesting to rely on more than one sampling method in order to obtain results close to reality, and the technique thus proposed in this present study seems fairly precise and compatible with other random sampling methods and does not present any ecological constraints.

\section{REFERENCES}

Adam Y., Béranger C., Delzons O., Frochot B., Gourvil J., Lecomte P. \& Parisot-Laprun M., 2015. Guide des méthodes de diagnostic écologique des milieux naturels. Application aux sites de carrière. UNPG, Paris, $388 \mathrm{pp}$.

Anonyme, 2011. Monographie de la wilaya de Tébessa. Document interne de la direction de planification et de l'aménagement du territoire.

Badenhausser I., 2012. Estimation d'abondance des criquets (Orthoptera: Acrididae) dans les écosystèmes prairiaux. Annales de la Société entomologique de France (N.S.), 48: 397-406.

Barataud J., 2005. Orthoptères et milieux littoraux. Influence de la gestion des habitats herbacés sur les ressources trophiques et enjeux pour la biodiversité. BTS Gestion des espaces Naturels, Session 20032005, Réserve Naturelle de Moëze, 86 pp.

Benkenana N. \& Massa B., 2017. A new species of Pamphagus (Orthoptera: Pamphagidae) from Algeria with a key to all the species of the genus. Zootaxa, 4254: 102-110 https://doi.org/10.11646/zootaxa.4254.1.6

Bentamer N., 1998. Disponibilités en ressources entomologiques et modalités de leur utilisation par deux échassiers: la Cigogne blanche (Ciconia ciconia) et le Héron garde bœufs (Bubulcus ibis) dans la vallée du Sébaou (Kabylie, Algerie). Thèse Magister, Institut National Agronomique El-Harrach, Alger, Algérie, 185 pp.

Boitier E., 2004. Caractérisation écologique et faunistique des peuplements d'Orthoptères en montagne Auvergnate. Matériaux Orthoptériques et Entomocénotiques, 9: 43-78.
Boitier E., 2005. Inventaire et caractéristique écologique des peuplements d'Orthoptères des zones sommitales de la Réserve naturelle de la Haute Chaine du Jura. Rapport Diren Rhône-Alpes, Réserve naturelle de la Haute Chaine du Jura et Alcide-Orbigny, Clermont-Ferrand (décembre 2005): 1-64.

Bouguessa S., 2018. Contribution à l'étude bioécologique des Orthoptères de la région de Tébessa. Thèse doctorat en Sciences. Université Badji-Mokhtar, Annaba.

Boukhemza M., Doumandji S., Voisin C. \& Voisin J. F., 2000. Disponibilités des ressources alimentaires et leur utilisation par le Héron garde-bœufs, Bubulcus ibis, en Kabylie, Algérie. Terre et Vie (Revue d'Écologie), 55: 361-381.

Boukhtache N., 2009. Contribution à l'étude de la niche écologique de la Cigogne Blanche Ciconia ciconia L., 1758 (Aves, Ciconiidae) et du Héron garde-bœufs Bubulcus ibis L., 1758 (Aves, Ardeidae) dans la région de Batna. Mémoire Magister, gestion des ressources naturelles et de l'environnement, Université de Batna.

Bouras D. \& Ramdani M., 2013. Evaluations écologiques de l'ile Rachgoun en vue d'un classement en aire marine protégée (ouest algérien). Rapports et procés-verbaux des réunions Commission internationale pour l'exploration scientifique de la Mer Méditerranée, pp. 1-40.

Bredin D., 1984. Régime alimentaire du Héron gardebœuf a la limite de son expansion géographique récente. Terre et Vie (Revue d'Écologie), 39: 431-445.

Chopard L., 1943. Orthoptéroides de l'Afrique du nord. Coll. Faune de l'empire français, T.I. Librairie Larose, Paris, $450 \mathrm{pp}$.

DATB, 1996. Annuaire statistique de la wilaya de Béjaïa. Direction Plan. Aménag. Ter. Wilaya Béjaïa.

Dajoz R., 1985. Précis d'écologie. Ed. Dunod, Paris, 505 pp.

Doumandji S., Doumandji-Mitiche B. \& Hamadache H., 1992. Place des Othoptères en milieu agricole dans le régime alimentaire du Héron garde-boeufs $(B u$ bulcus ibis. L.) à Drâa EI-Mizan en grande Kabylie (Algérie). Medicine Faculty "Landbouw" Ghent University, 57: 675-678.

Doumandji S., Harizia A., Doumandji-Mitiche B. \& Ait Mouloud S.K., 1993. Régime alimentaire du Héron garde-boeufs, Bubulcus ibis, en milieu agricole dans la région de Chlef (Algérie Medicine Faculty "Landbouw" Ghent University, 58: 365-372.

Doxon E.D., Davis C.A. \& Fuhlendorf S.D., 2011. Comparison of two methods for sampling invertebrates: vacuum and sweep-net sampling. Journal of Field Ornithology, 82: 60-67.

Fellag M., 2006. Ecologie trophique des poussins de la Cigogne blanche (Ciconia ciconia Linne 1758) dans la vallée de Sébaou en Kabylie (Algérie). Mémoire de Magister Sciences Agronomiques, Institut National Agronomique El-Harrach, Alger, Algérie. 
Franceschi P., 1994. La faune de vertébrés Corse. Quelques remarques sur sa spécificité, son origine, son évolution. Adecec-Cervioni, 12 pp.

Gardiner T., Hill J. \& Chesmore D., 2005. Review of the methods frequently used to estimate the abundance of Orthoptera in grassland ecosystems. Journal of Insect Conservation, 9: 151-173.

Georges A., Gueguen A. \& Steine C., 1999. Coléoptères carabiques et Orthoptères des jachères en tant que ressources potentielles de l'Outarde canepetière (Tetrax tetrax). Inventaire et cartographie des Invertébrés comme contribution a la gestion des milieux naturels français. Actes du séminaire tenu à Besançon les 8,9 et 10 juillet 1999. Patrimoines naturels, pp. 209-214.

Gherbi-Salmi R., 2013. Etude de l'Éco éthologie trophique du Héron garde-bœufs Bubulcus ibis Linné, 1758 (Aves, Ardeidae) dans la Kabylie de la Soummam (Bejaia). Thèse doctorat en Sciences. Université Abderrahmane Mira, Béjaia, 204 pp.

Gillon Y., 1967. Principes et méthodes d'échantillonnage des populations naturelles terrestres en écologie entomologique. Office de la Recherche Scientifique et Technique Outre-mer, Centre d'Aùiopodoumé, Côte d'Ivoire, décembre 1967, 55 pp.

Guéguen A., 1989. Cartographie et qualités bioindicatrices des Orthoptères. In: Utilisation des inventaires d'invertébrés pour l'identification et la surveillance d'espaces de grand intérêt faunistique. Ed. Secrétariat de la Faune et de la Flore, pp. 135-139.

Hafner H., Dugan P.J., Kersten M., Pineau O. \& Wallace J.P., 1993. Flock feeding and food intake in little egrets Egretta garzetta and their effects on food provisioning and reproductive success. Ibis, 135: 25-32.

Hafner H. \& Fasola M., 1992. The relationship between feeding habitat and colonially nesting Ardeidae - In: Finlayson C.M., Hollis G.E. \& Davis T.J. (Eds.), Managing Mediterranean wetlands and their birds, pp. 194-201. IWRB, Special Publication, No.20. International Waterfowl and Wetlands Research Bureau, Slimbridge, UK.

Hamadi K., Moulai R., Doumandji-Mitiche B., Tighidet Z. \& Khaldi Z., 2005. Etude de la faune Orthoptérologique dans la région de Béjaia - VIème Journée Nationale d'Acridologie, Institut National Agronomique, El Harrach, 6 mars 2005.

Jaulin S., 2004. Inventaire des Orthoptères des estives du Massif de l'Albère (66). Inventaire et orientations de gestion. Office pour les Insectes et leur Environnement, OPIE-LR, $31 \mathrm{pp}$.

Jaulin S., 2009. Etude des Orthoptères des sites expérimentaux du LIFE Basses Corbières. Synthèse des 4 années de prospections. Rapport d'étude de l'OPIE, Perpignan, $51 \mathrm{pp}$.
Jaulin S. \& Baillet Y., 2007. Identification et suivi des peuplements de Lépidoptères et d'Orthoptères sur l'ENS du Col du Coq. Pravouta. Rapport d'étude de l'OPIE-LR, Perpignan, 107 pp.

Le Moal L., 2002. L'analyse en composantes principales. LACP sous SPSS. Document de recherche [En ligne]. http://www.lemoal.org/download/spss/ACP.pdf.

Louveaux A., Amédégnato C., Poulain S. \& DesutterGrandcolas L., 2020. Orthoptères Acridomorpha de l'Afrique du Nord-Ouest (Version 2020), http://acrinwafrica.mnhn.fr.

Magurran A.E., 1988. Ecological diversity and its measurement. University Press, Cambridge, $177 \mathrm{pp}$.

Puissant S., 2003. Les Orthoptères comme outil d'aide à la gestion des sites de reproduction du grand Tétras, première contribution. Office pour les Insectes et leur Environnement, OPIE-LR, $16 \mathrm{pp}$.

Ramade F., 1984. Eléments d'écologie, écologie fondamentale. Ed. Mc Graw-Hill, Paris, 397 pp.

Roques O. \& Jourde P. (Coords. éd), 2013. Clé des Orthoptères de Poitou-Charentes. Poitou-Charentes Nature, Fontaine-le-Comte, 92 pp.

Sbiki M., 2016. Contribution à l'étude du régime alimentaire et de la biologie de reproduction de la $\mathrm{Ci}$ gogne blanche (Ciconia ciconia, Aves, Ciconiidae) et du Héron gardeboeufs (Ardea ibis, Aves, Ardeidae) dans la région de Tébessa. Thèse doctorat en Sciences. Université Batna2, Algeria, 202 pp.

Shannon C.E. \& Weaver W., 1948. The mathematical theory of communication. Urbana, University of Illinois Press.

Si Bachir A., Hafner H., Tourenq J. N., Doumandji S. \& Lek S., 2001. Diet of the adult Cattle egret (Bubulcus ibis L.) in a new North African colony (Soummam Kabylie, Algeria): taxonomic composition and variability. Ardeola, 48: 217-233.

Skov H., 1991. The ecology of the white stork (Ciconia ciconia) in Denmark. In: Mériaux J.L. (Ed.), Actes du colloque international, Les cigognes d'Europe. Institut Européen d'écologie / Association Multidisciplinaires des biologistes de l'environnement, Metz (France), pp. 33-36.

Tatin L., Dutoit T. \& Feh C., 2000. Impact du pâturage par les chevaux de Przewalski (Equus preswalskii) sur les populations d'orthoptères du causse Méjean (Lozère, France). Terre et Vie (Revue d'Écologie), 55: 241-261.

Voisin J.-F., 1980. Réflexion à propos d'une méthode simple d'échantillonnage des peuplements d'Orthoptères en milieu ouvert. Acrida, 9: 159-170.

Voisin J.-F., 1986. Une méthode simple pour caractériser l'abondance des Orthoptères en milieu ouvert. L'Entomologiste, 42: 113-119. 